\title{
En etisk diskussion af screening for kræftsygdomme
}

\author{
John Brodersen, Peter Laurs Sorensen, Fía Lindenskov og \\ Lonny Henriksen
}

I 2007 gennemførte forbundskansler Angela Merkel en sundhedsreform der blandt andet indeborer, at tyske borgere ikke frit kan afgøre, om de vil deltage $i$ forebyggende programmer, da et fravalg kan medføre økonomiske konsekvenser. Hermed udvider den tyske stat sin ret til at gribe ind i borgernes liv, når det handler om sekundoer forebyggelse, fx i form af screening for kroftsygdomme. Dette kan vore problematisk da den bedst tilgangelige evidens viser at tre igangvorende kræftscreeningsprogrammer ikke kun har gavnlige virkninger, men også betydelige skadelige virkninger. Formålet med denne undersøgelse var at undersøge, hvilke holdninger eksperter, politikere og sundhedsmyndigheder i Danmark har til tvang og/eller belønning i forbindelse med screening for kroftsygdomme, og om de ville støtte eller fraråde en tysk model i det danske sundhedsvoesen.

Der blev foretaget enkeltinterviews med strategisk udvalgte eksperter. Interviewene blev transskriberet og analyseret med en fonomenologisk analysemetode, og derefter analyseret og diskuteret i forhold til utilitaristisk og deontologisk etik, samt evidensen vedrørende de tre eksisterende kroftscreeningsprogrammer i Danmark.

Alle informanterne var kritiske over for det tyske forslag. Til gengold blev forholdet mellem de gavnlige og skadelige virkninger af kroftscreening vurderet meget forskelligt. Manglen på enighed, uklare udtalelser og ikke-stringent terminologi bestyrkede vor konklusion; at det danske sundhedsvoesen for det første ikke bør følge den tyske kurs og, for det andet, at man bør vore kritisk over for implementering af screeningsprogrammer for kroftsygdomme. Hvis forebyggende initiativer kan vore mere til skade end gavn, bør de altid overvejes nøje i lyset af sundhedsvosnets oprindelige intention om at hjoelpe og beskytte det enkelte menneske.

Nøgleord: screening, kræftsygdomme, utilitarisme, deontologi, fænomenologi 


\section{Indledning}

Den 16. februar 2007 proklamerede forbundskansler Angela Merkel, at Tysklands nye sundhedsreform var blevet vedtaget, og den 1. april 2007 trådte reformen i kraft.

Reformen betød blandt andet, at enhver tysk borger ikke længere frit kunne afgøre om han eller hun ville deltage i et forebyggende program, f.eks. screening for kræftsygdomme, da et fravalg ville blive straffet.

I processen før reformen blev vedtaget, blev der fremsat et lovforslag, der gik ud på, at patienter med en kræftsygdom, som ikke har fulgt screeningsundersøgelserne før deres kræftsygdom diagnosticeres, skulle bidrage med $2 \%$ af deres indkomst til sygekassen imod $1 \%$, som andre patienter med kroniske sygdomme skulle betale. Forslaget, som tydeligvis indebar en direkte straf for dem, som ikke deltog i et screeningsprogram, blev senere reformuleret. Den nye formulering eliminerede imidlertid ikke statens mulighed for at gennemføre sanktioner over for befolkningen i forbindelse med forebyggelsesprogrammer.

Borgerne skulle dokumentere, at de havde deltaget i de tilbudte screeningsundersøgelser og ved fremmøde til undersøgelserne medbringe en folder, hvori det markeredes, hvilke forebyggende undersøgelser, de havde deltaget $\mathrm{i}, \mathrm{og}$ hvornår de har fåt dem foretaget.

Da sundhedsreformen var omfattende, ville folderen utvivlsomt blive et nyttigt instrument i den tyske stats forsøg på at sikre, at flest mulige borgere deltog.

I Tyskland anbefales det at alle tyske borgere over 55 år hvert andet år undersøges for skjult blod i afføringen og får foretaget en kikkertundersøgelse af ende- og tyktarm hvert 10. år, begge dele som led i en screening for tarmkræft. Yderligere skal mænd, fra de er 45 år, hvert år gennemgå en screeningsundersøgelse for prostatakræft. Kvinder skal screenes for brystkræft med mammografiundersøgelse, fra de er 30 år, samt hvert andet år fra de er 50 til 69 år. Unge kvinder skal screenes for livmoderhalskræft hvert år, fra de er 20 år (Tuff 2006; Bundesministerium für Gesundheit 2008a).

Alle disse screeningsundersøgelser vil medføre, at en mand, når han bliver 80 år gammel, vil have gennemgået 50 screeninger for kræftsygdomme, og en kvinde på 80 år vil have gennemgået 135 screeningsundersøgelser.

Reformen vil altså i meget høj grad inddrage befolkningen i den tyske stats forebyggende arbejde, hvilket på længere sigt kan begrænse omfanget af visse sygdomme. Men man kan spørge sig selv om, hvor vidt staten optræder retfærdigt og etisk korrekt over for sine borgere, når den indfører sanktioner. Dette bliver ikke bedre af den ubalance der er mellem gavnlige og skadelige effekter af de mange screeningsundersøgelser, som vi senere beskriver.

Med hensyn til det rimelige i statens sanktioner, skal det bemærkes, at princippet med at man skal betale en større andel, hvis man ikke deltager i 
forebyggende foranstaltninger, ikke er nyt i Tyskland. Går man ikke til regelmæssige tandeftersyn, skal man f.eks. selv betale en større andel af udgifterne.

Alligevel delte diskussionen om den økonomiske sanktion ved screeningsundersøgelser den tyske regering i to. Modstanderne kaldte forslaget for skandaløst, en økonomisk diskrimination, kynisk og grotesk, mens sundhedsminister Ulla Schmidt forsvarede regeringens planer ved at sige, at det ikke var for at straffe patienterne, men for at opmuntre til en sundere adfærd (Tuff 2006).

Inden sundhedsreformen trådte i kraft, valgte den tyske regering at formulere sanktionen ved screeningsprogrammer og andre former for forebyggelse som: «forsikrede, som selv gør noget for deres sundhed, for eksempel ved at følge forebyggende undersøgelser, skal belønnes af deres sygekasse». ${ }^{1}$

I stedet for „straf» taler regeringen om en belønning til de borgere, som gør en indsats for egen sundhed. Belønningen består i, at man, hvis man udvikler en kronisk sygdom og har fulgt forebyggende undersøgelser, skal betale $1 \%$ til sygekassen i stedet for $2 \%$. At ændre ordet «straf» til «belønning» ændrer imidlertid ikke ved, at der fortsat vil være borgere, som bliver tvunget til at deltage i de forebyggende programmer. Dette finder vi bekymrende, dels fordi der er evidens for, at de mange undersøgelser som befolkningen udsættes for, kan have skadelige konsekvenser, dels fordi den tyske idé om sanktioner i forbindelse med folkesundhedsarbejdet kunne danne præcedens for andre landes sundhedspolitik. Her er spørgsmålet, om et lignende dansk lovforslag kunne forenes med den gældende opfattelse af forholdet mellem borger og stat/sundhedsvæsen i Danmark?

Inden vi tager hul på diskussionen om skadelige konsekvenser ved screening og det ligeså vigtige spørgsmål om statens rolle i det forebyggende sundhedsarbejde, vil vi først definere begrebet «medicinsk screening» og se nærmere på to igangværende og ét muligt kommende screeningsprogram.

\section{Screening}

Medicinsk screening er sekundær profylakse, der defineres som tidlig opsporing af sygdom, forstadier til sygdom og/eller risikofaktorer (Det etiske råd 1999; Sundhedsstyrelsen 1990; Wilson \& Jungner 1968). Formålet med medicinsk screening er at helbrede eller forbedre prognosen for de personer, som ved screening får konstateret en abnorm tilstand (Morabia \& Zhang 2004). Ordet «screening» betyder i denne kontekst en grovsortering eller en sigtning. Oprindeligt stammer ordet fra den proces, hvor kul og slagger skilles ad, og hvor metalriste med forskellige afstand mellem gitrene sorterer kulstykkerne i relativt ens størrelser - screening the coal. 
Screening kan foretages af en gruppe personer, der har en forhøjet risiko for en kendt sygdom, men screening kan også foretages af en almindelig befolkningsgruppe uden specielle risici. I resten af artiklen vil ordet «screening» alene blive anvendt om screening af en almindelig befolkningsgruppe. Når en befolkningsgruppe inviteres til screening, vil de personer, der undersøges med henblik på tidlig opsporing af sygdom, forstadier til sygdom eller risikofaktorer, være personer, som ikke på forhånd har mistanke om at fejle noget, eller som ikke har symptomer på de sygdomme, der screenes for (Sundhedsstyrelsen 1990).

Da screeningproceduren er en grovsortering af personer med eller uden sygdom, er der risiko for, at der kan opstå «fejl». Ved medicinsk screening kan raske personer fejlagtigt få at vide, at de muligvis er syge, et såkaldt falsk positivt screeningssvar eller en falsk alarm. Screeningsprocessen kan også resultere $i$, at syge mennesker fejlagtigt får at vide, at der ikke er mistanke om, at de er syge, selvom de er det, et såkaldt falsk negativt svar eller en falsk tryghed. De fire mulige udfald af screeningsprocessen er illustreret $i$ tabel 1.

Tabel 1. Mulige udfald af en medicinsk screeningsproces

\begin{tabular}{|l|l|l|}
\hline & Person med sygdom & Rask person \\
\hline Positiv screening test & Sandt positivt svar & Falsk positivt svar \\
\hline Negativ screening test & Falsk negativt svar & Sandt negativt svar \\
\hline
\end{tabular}

Da der således kan forekomme såvel sande som falske svar, har screening ikke kun potentielle gavnlige virkninger, men også potentielle skadelige. Disse kan efter Holland og Stewart (2005) opstilles som i tabel 2 på næste side. 
Tabel 2: Gavnlige og skadelige virkninger af screening

\begin{tabular}{|l|l|}
\hline Screenings gavnlige virkninger & Screenings skadelige virkninger \\
\hline $\begin{array}{l}\text { Forbedret prognose for nogle af } \\
\text { dem, der bliver fundet med syg- } \\
\text { dom/forstadier til sygdom/risiko- } \\
\text { faktorer }\end{array}$ & $\begin{array}{l}\text { Et liv med længere tid som syg, for } \\
\text { nogle af dem, der bliver fundet } \\
\text { med sygdom/forstadier til sygdom/ } \\
\text { risikofaktorer, og som ikke får æn- } \\
\text { dret deres prognose }\end{array}$ \\
\hline $\begin{array}{l}\text { En mindre intensiv behandling for } \\
\text { nogle af dem, der bliver fundet } \\
\text { med sygdom/forstadier til sygdom/ } \\
\text { risikofaktorer }\end{array}$ & $\begin{array}{l}\text { Overbehandling af de personer } \\
\text { som får falsk positive screenings- } \\
\text { svar } \\
\text { 2) får konstateret forstadier til } \\
\text { sygdom, som uden behandling } \\
\text { aldrig ville være progredieret til } \\
\text { egentlig sygdom eller spontant } \\
\text { ville regrediere } \\
\text { 3) overdiagnosticeres }\end{array}$ \\
\hline $\begin{array}{l}\text { Følelse af tryghed for dem, der får } \\
\text { negative testresultater }\end{array}$ & $\begin{array}{l}\text { En falsk følelse af tryghed for dem, } \\
\text { der får falsk negative screenings- } \\
\text { svar }\end{array}$ \\
\hline $\begin{array}{l}\text { Negative psykosociale følger af } \\
\text { falsk positive svar }\end{array}$ \\
\hline $\begin{array}{l}\text { Overdiagnosticering af sygdom, } \\
\text { som aldrig ville være blevet til } \\
\text { symptomgivende sygdom inden } \\
\text { for personens levetid (Raffle 2003; } \\
\text { Gøtzsche \& Nielsen 2006) }\end{array}$ \\
$\begin{array}{l}\text { Morbiditet og død som følge af det } \\
\text { efterfølgende udredningsprogram } \\
\text { blandt personer med falsk positive } \\
\text { svar (A \& B) }\end{array}$ \\
\hline
\end{tabular}

I tabellen er der tilføjet to afgørende dokumenterede skadelige virkninger ved screening, som ikke medtages i Holland og Stewarts oprindelige tabel, nemlig: overdiagnosticering og morbiditet/dødsfald blandt raske personer, der får falsk positive screeningssvar.

Overdiagnosticering af kræftsygdomme eller forstadier til disse og morbiditet/dødsfald blandt raske personer, der får falsk positive screeningssvar, er dokumenterede skadelige virkninger ved screening for kræftsygdomme 
(Raffle 2003; Gøtzsche \& Nielsen 2006). Der er således en risiko for morbiditet/dødsfald blandt raske personer, der får falsk positive screeningssvar, samt mulige negative psykosociale konsekvenser blandt de samme raske personer, når de får rejst mistanke om at have en kræftsygdom uden at have det. Der bør derfor tilstræbes et minimum af falsk positive screeningssvar ved screening for kræftsygdomme. Sammen med overdiagnosticering er de falsk positive screeningssvar ofte afgørende for den etiske vurdering af kræftscreeningsprogrammers værdi. Det vil sige, om man ud fra et etisk synspunkt kan forsvare at tilbyde et screeningsprogram for en given kræftsygdom til den almindelige befolkning. På den ene side må man ikke overse en behandlingskrævende kræftsygdom, på den anden side må der ikke være for mange personer, der unødigt bliver gjort til patienter med kræftsygdomme, endsige for mange personer, der får falske positive screeningssvar.

I Danmark tilbydes den kvindelige del af befolkningen i øjeblikket to screeningsprogrammer for kræftsygdomme, nemlig for brystkræft, som tilbydes i form af mammografiscreening hvert andet år til kvinder mellem 50 og 69 år, og livmoderhalskræftscreening, som tilbydes hvert tredje år til kvinder mellem 23 og 59 år. Desuden er der i Danmark foretaget gennemførlighedsundersøgelser i to amter af screening for ende- og tyktarmskræft (tarmkræft). På baggrund af erfaringerne indhentet i gennemførlighedsundersøgelserne, anbefaler den danske Sundhedsstyrelse at screening for tarmkræft (vha. en afføringsprøve for ikke-synligt blod) bliver et generelt tilbud til alle danskere mellem 50 og 75 år (Sundhedsstyrelsen 2008).

Med udgangspunkt i David Sackett og kollegaers definition af evidensbaseret medicin (Sackett 1996), har vi ud fra den bedst tilgængelige viden angivet de mulige gavnlige og skadelige virkninger af mammografiscreening, livmoderhalskræftscreening og tarmkræftscreening i tabel 3, således at antal undgåede dødsfald af kræft er sat i forhold til antal overdiagnosticerede og antal falsk positive screeningssvar. 
Tabel 3

\begin{tabular}{|c|c|c|}
\hline Screeningsprogram & $\begin{array}{l}\text { Antal undgåede } \\
\text { dødsfald }\end{array}$ & $\begin{array}{l}\text { Antal falsk positive } \\
\text { svar og antal } \\
\text { overdiagnosticerede }\end{array}$ \\
\hline $\begin{array}{l}\text { Screening for livmoder- } \\
\text { halskroeft (Raffle 2003) } \\
\text { - Når } 1.000 \text { kvinder } \\
\text { screenes hvert 3. år } \\
\text { over } 35 \text { år vil }\end{array}$ & $\begin{array}{l}\text { - } 1 \text { dødsfald af livmo- } \\
\text { derhalskræft forebyg- } \\
\text { ges }\end{array}$ & $\begin{array}{l}\text { - } 150 \text { vil få et abnormt } \\
\text { screeningssvar } \\
\text { - hvoraf } 80 \text { har celle- } \\
\text { forandringer } \\
\text { - hvoraf } 50 \text { vil blive } \\
\text { unødigt keglesnitope- } \\
\text { reret }\end{array}$ \\
\hline $\begin{array}{l}\text { Screening for brystkreft } \\
\text { (Gøtzsche \& Nielsen } \\
\text { 2006) } \\
\text { - Når } 2.000 \text { kvinder in- } \\
\text { viteres til mammogra- } \\
\text { fiscreening hvert andet } \\
\text { år fem gange på ti år vil }\end{array}$ & $\begin{array}{l}\text { - } 1 \text { dødsfald af bryst- } \\
\text { kræft forebygges }\end{array}$ & $\begin{array}{l}\text { - } 200 \text { vil få falsk positi- } \\
\text { ve svar. } \\
\text { - } 10 \text { overdiagnostice- } \\
\text { res og behandles }\end{array}$ \\
\hline $\begin{array}{l}\text { Screening for tarmkreft } \\
\text { (Hewitson et al. 2007) } \\
\text { - Når } 1.350 \text { personer } \\
\text { inviteres til tarm- } \\
\text { kræftscreening hvert } \\
\text { andet år fem gange på } \\
\text { ti år vil }\end{array}$ & $\begin{array}{l}\text { - } 1 \text { dødsfald af tarm- } \\
\text { kræft forebygges }\end{array}$ & $\begin{array}{l}\text { - } 125 \text { får falsk positive } \\
\text { svar og alle koloskope- } \\
\text { res } \\
\text { - hvoraf mindst } 56 \text { ( } 45 \\
\% \text { ) har tarmpolypper } \\
\text { og bliver polypekto- } \\
\text { meret } \\
\text { - hvoraf } 0,5 \text { får perfo- } \\
\text { ration af tarmen } \\
\text { - hvoraf } 0,03 \text { (ca. } 1 \text { ud } \\
\text { af } 1.800 \text { ) dør som kon- } \\
\text { sekvens af perforatio- } \\
\text { nen }\end{array}$ \\
\hline
\end{tabular}

De screeningsprogrammer for kræftsygdomme, som allerede er tilgængelige eller muligvis vil blive indført i Danmark, kan altså alle tre medføre både gavnlige og skadelige virkninger for den enkelte screeningsdeltager. Dette skaber et vanskeligt valg for den enkelte borger når denne inviteres til screening, forudsat at borgeren informeres på en fyldestgørende og forståelig måde, hvor de gavnlige og skadelige virkninger af screening kan sammenlignes (www.screening.dk (2008); www.cochrane.dk (2008); Brodersen et al. 2008). Men det at screeningsprogrammer både har gavnlige og 
skadelige virkninger, virker også uforeneligt med et forslag om tvang eller belønning, som foreslået af den tyske regering.

Formålet med denne undersøgelse var derfor at undersøge, hvilke holdninger eksperter, politikere og sundhedsmyndigheder i Danmark har til tvang og/eller belønning i forbindelse med screening for kræftsygdomme som angivet i den tyske lov, og om de, givet den tilgængelig evidens på området, ville støtte eller fraråde en sådan tysk model i det danske sundhedsvæsen.

\section{Materiale og metode}

Fra 12. til 23. april 2007 blev der gennemført semi-strukturerede enkeltinterviews (Malterud 2003) med informanter fra fem forskellige institutioner der havde relationer til forskellige aspekter omkring screening for kræftsygdomme.

De fem informanter blev strategisk udvalgt ud fra den relevans deres respektive fag og myndighedsområder dækkede i forhold til formålet med undersøgelsen. Informanterne blev kontaktet enten fordi de er hovedansvarlige i forhold til screening-/kræftområdet, eller fordi de er institutionens ansigt udadtil.

De pågældende informanter fik hver især tilsendt en invitation til et interview. I invitationen blev de informeret om problemstillingen og formålet med interviewet. Tidspunktet og stedet for interviewet blev aftalt pr. telefon.

Informanterne var:

- Et medlem fra Det Etiske Råd, for at belyse problemfeltet i et etisk perspektiv.

- En medarbejder i Forbrugerrådet, som varetager de danske borgeres interesser over for myndighederne. Her er det forholdet mellem borger og stat, som er perspektivet.

- En ledende ansat i Kræftens Bekæmpelse, som er en patientforening, der varetager patienter med kræft og deres pårørendes interesser. Her belyses patientperspektiv.

- En ledende ansat i Sundhedsstyrelsen, for at opnå kendskab til anbefalinger og retningslinjer i et medicinsk perspektiv.

- En politiker inden for sundhedsområdet, for at belyse forholdet i et politisk perspektiv.

Informanterne betegnes herefter som «N», med tallene 1-5. Sløringen er foretaget af hensyn til informanternes anonymitet. Tallene stemmer ikke nødvendigvis overens med rækkefølgen i vore interviews. 
Indledningsvist fik alle informanter tilsendt artiklen fra 2006 om det tyske forslag fra British Medical Journal (Tuff 2006) med opfordring til at læse den inden interviewet.

\section{Interviewguide}

Med udgangspunkt i projektets formål, blev der gennemført en systematisk litteratursøgning, som dannede grundlag for udarbejdelsen af en emneinddelt interviewguide. Ved hjælp af to af forfatternes fagområder, medicinsk screening og videnskabsteori og etik, blev interviewguiden udformet således, at de mulige etiske dilemmaer ved screening for kræftsygdomme kunne anskueliggøres gennem informanternes holdninger til det tyske forslag.

Interviewguiden indeholdt seks styrende aspekter, som blev anvendt som kategorier; 1) det tyske forslag, 2) tvang, 3) screening, 4) kriterierne, 5) etiske teorier samt 6) ansvar for sundhed.

Interviewguiden blev fortløbende videreudviklet ved de semi-strukturerede interviews (Kvale, 1997).

\section{Analyse}

Analysen af interviewdata tager udgangspunkt i Kvales beskrivelse af «meningskategorisering». Alle fem interviews blev optaget på en diktafon og herefter transskriberet. Transskriptionerne blev for hvert interview gennemlæst flere gange for at få et overblik over materialet og for at skabe en overordnet forståelse af, hvilke kategorier, der kunne være meningsbærende. Interviewene blev analyseret med fænomenologisk tilgangsvinkel ad modum Malterud (Malterud 2003).

Der blev foretaget en vertikal kodning af hvert interview med henblik på at identificere de centrale meninger. Derefter blev der foretaget en horisontal kodning på tværs af alle interviews, hvor de centrale meninger fra hvert interview blev kategoriseret. Det sidste trin i analysen var at udarbejde en sammenfatning af meningskondenseringer fra hver af informanterne for at tydeliggøre, hvilke erfaringer informanterne har på screeningsområdet inden for de forskellige kategorier.

Ifølge Kvale er meningskondensering ensbetydende med, at den interviewedes mening trækkes sammen til en kortere mening, hvor hovedbetydningen af det sagte omformuleres i få ord, og lange interviewtekster reduceres til korte præcise formuleringer (Kvale 1997).

Der blev til sidst gennemført en pålidelighedstest, hvor interviews og meningskondenseringer blev gennemgåt for mangler eller direkte fejl. 


\section{Resultater}

Følgende oversigt illustrerer, hvordan de fem interviews blev kodet med kategorier og meninger. Oversigten dækker et bredt udsnit af meningskondenseringerne. De udvalgte meninger er tilfældige eksempler.

\begin{tabular}{|c|c|}
\hline Kategorier & Meningskondensering \\
\hline Det tyske forslag & $\begin{array}{l}\text { Synes forslaget er udmærket, men det er ikke } \\
\text { ligestilling. } \\
\text { Forslaget vil ligge til grund for at man ændrer } \\
\text { mange ting. } \\
\text { Det tyske forslag er et symptom på det der sker } \\
\text { i Europa og den vestlige verden. }\end{array}$ \\
\hline Tvang & $\begin{array}{l}\text { Man kan ikke tvinge folk. } \\
\text { Tvang er for stærkt et ord, kan bedre lide ordet } \\
\text { «obligatorisk». } \\
\text { Ikke belæg for tvang, det skal være et tilbud. }\end{array}$ \\
\hline Screening & $\begin{array}{l}\text { Screening er udtryk for at vi tror vi kan gøre os } \\
\text { usårlige. } \\
\text { Screeningstilbud er gode, man finder knuder meget } \\
\text { tidligt. } \\
\text { Hvis der findes screeningsprogrammer, som giver } \\
\text { pote, så skal man sætte ind i tide og spare ressourcer. }\end{array}$ \\
\hline Kriterierne & $\begin{array}{l}\text { Kriterierne for de tre screeninger er afvejet og } \\
\text { derfor bruger man dem. } \\
\text { Kan føre til stigmatisering. } \\
\text { Forslaget ligger ude for kriterierne eftersom } \\
\text { borgerne skal betale. }\end{array}$ \\
\hline Etiske teorier & $\begin{array}{l}\text { Samlet set gavner forslaget ikke de fleste. } \\
\text { Der vil altid være pligtetiske overvejelser. }\end{array}$ \\
\hline $\begin{array}{l}\text { Ansvar for } \\
\text { sundhed }\end{array}$ & $\begin{array}{l}\text { Sundhed er begge dele, så man kan ikke læne sig } \\
\text { tilbage og undres ved sygdom. } \\
\text { Der er en tendens til at se sygdom som den enkeltes } \\
\text { ansvar. } \\
\text { Det enkelte menneske må leve og det offentlige } \\
\text { træde i karakter og hjælpe. }\end{array}$ \\
\hline \begin{tabular}{|l|} 
Nye kategorier der \\
fremkom ved \\
analysen \\
- krav \\
- oplysning \\
- markedskræfter \\
\end{tabular} & $\begin{array}{l}\text { Der skal et rimeligt godt belæg til, hvis man vil stille } \\
\text { krav om bestemt adfærd. } \\
\text { Information som middel til at undgå stigmatisering. } \\
\text { Den nye tendens i det tyske forslag: øget } \\
\text { markedsgørelse, mere økonomisk incitament i } \\
\text { sundhedsvæsnet. }\end{array}$ \\
\hline
\end{tabular}




\section{Det tyske forslag}

Informanterne var enige om, at betaling for sundhedsydelser vil begrænse kontakten mellem samfundets svage grupper og sundhedsvæsnet, og derved øge den sociale ulighed i sundhed. Samtlige informanter var derfor imod forslaget.

Et andet gennemgående argument imod det tyske forslag var, at forslaget lægger op til, at sygdom bliver borgernes egen skyld. Når sygdom bliver ens egen skyld, er det ifølge N5, udtryk for stigmatisering. Og hvis man tilmed selv skal bøde for den sygdom, som samfundet mener, man er skyld i, bliver stemplingseffekten endnu mere udtalt.

Informant N1 påpegede faren for et skred i holdningen til sygdom og sundhed, som vil være begyndelsen på en glidebane, hvor det kan ende med, at der er flere områder, hvor borgeren uden videre gøres ansvarlig for sygdom.

N3 uddybede modstanden med, at det ville medføre store omvæltninger i hele sundhedsvæsnet - det tyske forslag «Vender op og ned på sundhedsvæsnet, som bygger på frivillighed, tilbud og ingen tvang». N4 afviste, at forslaget er de rette rammer, hvis der skal skabes en fornuftig holdning i befolkningen, ligesom N4 ikke så nogen økonomisk gevinst. Forslaget vil i sig selv udhule sundhedsvæsnet, og ifølge N4 er det «lige så meget bekymrende som den konkrete bekymring for forslaget».

Forslaget fik forargelsen til at vælde op i N5, da selve «grundlaget for at argumentere for, at det er så vigtigt at gå til screening, er [...] for tyndt».

Endelig mente N2, at «forslaget bygger på en grundholdning, vi ikke deler i Danmark», det fremmer hverken ligestilling eller borgernes frie valg. N3 påpegede, at forslaget indebærer anvendelse af tvang og krænkelse af folks rettigheder, og at det kan betyde, at dele af befolkningen ikke opsøger sundhedsvæsnet, når de faktisk har behov for hjælp.

\section{Tvang}

Informanterne delte samme holdning over for anvendelsen af tvang «man kan ikke tvinge nogen til at deltage i noget» (N2).

Informanterne blev spurgt om hvorvidt deres holdning til anvendelse af tvang ville ændre sig, hvis vi rent hypotetisk forestillede os et screeningsprogram, som kun havde gavnlige virkninger. Hertil svarede alle informanter fortsat, at man ikke kan anvende tvang. Heller ikke, hvis der ikke er skadelige virkninger. N3 uddybede svaret med, at selvom der rent hypotetisk kun var gavnlige virkninger, ville $\mathrm{N} 3$ stadig satse på et sundhedssystem, der bygger på frivillighed. Alle informanter var altså enige om, at sundhedsydelser skal være tilbud, og at det offentlige danske sundhedssystem, hvor der er lige adgang for alle, skal fastholdes. 


\section{Pisken eller guleroden}

Men informanterne var knap så enige, når de blev spurgt om det hensigtsmæssige i overhovedet at anvende straf (pisk) eller belønning (gulerod) over for befolkningen. Informant N3, N4, N5 var imod anvendelsen af både «pisk» og «gulerod». Men N1 så gerne, at man anvendte noget håndgribeligt som for eksempel en gave til dem, som deltager i eksempelvis screeningsundersøgelser.

\section{Screening}

Den kategori, hvor der viste sig at være mest uenighed, var screeningsområdet. Overordnet mente $\mathrm{N} 1, \mathrm{~N} 2 \mathrm{og} \mathrm{N} 4$, at screeningsprogrammer for kræftsygdomme overvejende er gavnlige, mens N3 og N5 ikke havde denne mening. N3 påpegede, som et problem, at «Man kan blive gjort til kræftpatient uden at være det» og mente, at man ikke kan forsvare anvendelsen af screeningprogrammer, før der er evidens for såvel skadelige som gavnlige virkninger.

N5 pegede på, at der er tre betingelser ${ }^{2}$ som skal være opfyldte, for at man kan forsvare anvendelsen af screening, og de tre betingelser er ikke opfyldte for de omtalte screeningsprogrammer. Derfor kan man ikke forsvare at anvende dem. Mere generelt mente N5 at misvisende informationer skaber problemer ved screening «De screenede tror, de kan beskytte sig mod sygdom. Screeningstilbud sælges i forenklet tilbud, derfor tror befolkningen, at det er rigtig godt».

N4 mente imidlertid, at hvis der findes screeningsprogrammer, som viser positiv effekt, så bør de anvendes. Screeningsprogrammer skal afvejes afhængigt af, om de får tilslutning fra borgerne. Er der borgertilslutning, så mener N4, at man skal anvende et givet screeningsprogram. Det skal dog diskuteres ud fra kriterierne for screening, om der er noget ved programmerne, som gør, at tilslutningen er lav. Hvis tilslutningen er lav, er der ingen grund til at iværksætte et program, og så må man selvfølgelig afveje om gevinsterne er økonomisk rentable.

\section{Kriterierne}

Kriterierne fra Sundhedsstyrelsen og WHO blev også bragt til diskussion ved alle 5 interviews. N4 og N1 mente, at kriterierne fra WHO fortsat er tilstrækkelige, hvad angår de screeningsprogrammer, der tilbydes i Danmark. N5 påpegede, at det tyske forslag ikke har taget højde for WHO’s kriterier. 


\section{Etiske teorier}

Blandt informanterne var der enighed om, at det tyske forslag ikke vil skabe mest nytte for flertallet. N3 begrundede sin holdning med den evidens, der findes på området. I forhold til det, der vides, vil det tyske forslag ikke gavne de fleste, og som N3 udtrykte det:

Så kan man forvente at man kommer til at bruge en masse penge af sundhedsvæsnets forholdsvis begrænsede ressourcer [...] hvor man til gengæld kommer til at skade en del af befolkningen [...] sundhedsvæsnet bliver selvforsynende på den måde, man selv skaber patienterne, hvis ikke de er der i forvejen.

Men der var uenighed blandt informanterne om det rimelige i den overordnede fordeling af ressourcerne i sundhedsvæsnet. N3 mente således, at hvis man ikke helt sikkert får noget ud af at bruge ressourcerne på raske mennesker, «så synes jeg rent faktisk at vi skal bruge vores penge på de som er syge, dem vi har konstateret er syge, og som har et behov».

N4 mente derimod, at man fortrinsvis bør bruge ressourcerne på forebyggelse, og gerne flere ressourcer, medens $\mathrm{N} 1$ påpegede, at det ikke handler om at bruge flere ressourcer. Det handler om, at sundhedsvæsnet bruger de tilgængelige ressourcer forkert. Endelig mener N5, at der er andre og vigtigere forpligtelser, samt at hele diskussionen er udtryk for en tro på «at vi kan gøre os usårlige, [...] vi tror vi skal screene hele den danske befolkning for, nær sagt, hvad som helst. Ressourcemæssigt er screening (red.) fejlanbragt».

\section{Ansvar for sundhed}

Informanterne var enige om, at sundhed både er et personligt og et offentligt anliggende. N4 uddybede med, at borgerne ikke bare skal læne sig tilbage og undres over, at de rammes af sygdom, de skal selv medvirke til en sund levevis. Staten gør efter N4's mening meget på oplysningssiden, men den skal passe på ikke at blive formynderisk og kun skabe regler.

$\mathrm{N} 3$ påpegede, at der er sket en holdningsændring. Sundhed er blevet den enkeltes ansvar og tilsvarende er livsstil- og livsstilsfaktorer kommet i fokus. N3 mente, at det er statens opgave at fastlægge rammerne for befolkningens levevis, uden at blande sig i det enkelte menneskes valg, også selvom valget har negative konsekvenser for sundheden. I tråd med dette mente $\mathrm{N} 1$, at det enkelte menneske må leve livet som det vil, men samtidig må staten også træde i karakter og hjælpe. Ifølge N5 træder staten netop ikke i karakter ved bare at give befolkningen ansvar for egen sundhed. Jo mere ansvar borgerne får, jo mere bliver sygdom også ens egen skyld.

«Hvis bare vi kan lade være med at ryge, motionerer nok, spiser rigtigt og tænker os om, så kan der ikke rigtig ske os noget ondt [...] når det så sker, så må det være en fejl» udtalte N5 og tilføjede at «Screening er et udtryk for 
at vi kan gøre os usårlige», eller med en anden rammende bemærkning: «Det er faktisk blevet en fejl at dø efterhånden».

\section{Yderligere kategorier}

Ved at gennemføre rækken af interviews, nærlæse og tematisere emner og meninger fremstod der yderligere tre kategorier: markedskræfter, krav og oplysning.

\section{Markedskræfter}

N1 mente, at sundhedsvæsnet skal være baseret på et folkestyret princip, som fastlægger de overordnede mål. Det skal ikke være de rå markedskræfter, som bestemmer målene. N1 så noget i det tyske forslag, som tyder på at sundhedsvæsnet ændrer sig fra offentlig finansiering med lige og fri adgang for alle borgere, til et markedsdrevent foretagende, hvor det handler om at tjene penge og sikre overskud. Hvis befolkningen ikke kan få ydelser over skatten, så vil den købe ydelserne gennem blandt andet sundhedsforsikringer. Det vil føre til, at det kun vil være de bedre stillede sociale grupper, som får mulighed for behandling. Alt i alt tog N1 skarpt afstand fra enhver egenbetaling i sundhedsvæsnet, og understregede, at staten skal respektere borgernes valg, uden at det får konsekvenser for tegnebogen.

$\mathrm{N} 4$ påpegede, at det også er vigtigt, at man i det offentlige sundhedssystem er tilbageholdende med de ydelser, som tilbydes. Selvom man kan købe sig ind på privathospitaler, så giver det offentlige fortsat et godt tilbud, uanset hvem man er, og hvilken indtægt man har. Politikerne må dog sætte grænser for statens tilbud, også selvom befolkningen forventer det bedste, og det har politikerne svært ved.

\section{Krav}

Informanterne var uenige om, hvem der kan stilles krav til og hvilke krav, der kan stilles. N2 udtrykte, at befolkningen stiller flere og flere krav til det offentlige, og at det kan få sundhedsudgifterne til at eksplodere. N3 pegede imidlertid på, at det er staten, som stiller krav til befolkningen om en bestemt adfærd, og fandt det i den forbindelse særdeles problematisk, at borgerne ikke oplyses tilstrækkeligt om de skadelige virkninger ved screening, ikke mindst i lyset af diskussionen om økonomiske sanktioner i det tyske forslag. Endelig mente N4, at staten ikke kan stille krav til befolkningen om deltagelse i de omtalte programmer, men snarere må oplyse noget mere. 


\section{Oplysning}

Informanterne var heller ikke enige om oplysning. N2 mente, at oplysning kunne være det middel, som fik folk til selv at gå ind i screeningsprogrammer og anvende sundhedsydelser mere aktivt. Og særligt oplysning i lægepraksis kunne modvirke stigmatisering.

Men N1 var dog af den opfattelse, at når der er divergerende udsagn fra fagfolk, så er det svært for befolkningen at vide, hvad den skal tro. Generelt mente N1, at befolkningen er overinformeret og endnu værre er det, at den oplysning, som eksisterer, er alt for unuanceret. Som en forbedring foreslog N1, at læger/fagfolk skal sætte sig sammen og finde frem til, hvad der helt præcist kan anbefales.

\section{Diskussion}

Et gennemgående resultat af undersøgelsen er, at alle informanter var imod det tyske forslag om at bruge tvang og/eller belønning i forhold til screening for kræftsygdomme. Informanternes modstand mod det tyske forslag var begrundet $\mathrm{i}$, at de mente forslaget vil pålægge patienterne ansvaret for deres kræftsygdom, hvilket vil føre til en øget stigmatisering af dem, som rammes af kræft. Men modstanden var ikke entydig hvilket må bero på informanternes forskellige interesser og positioner i diskursen om kræftsygdomme og forebyggelse. Det er således tydeligt, at evidensen for gavnlige, henholdsvis skadelige effekter ved screening vurderedes forskelligt af informanterne.

Ligesom andre former for teknologi kan screening være til gavn for befolkningen, men de mulige gavnlige effekter af et screeningsprogram må afvejes i forhold til de skader det kan forvolde. Staten kan være forpligtet til at gribe ind over for visse sygdomme, f.eks. AIDS, og derved udøve formynderiske handlinger, som kan opfattes som urimelige i dele af befolkningen. Det fratager dog aldrig myndighederne ansvaret for, fra sag til sag, at overveje om et givet indgreb, uanset dets måske gavnlige konsekvenser, faktisk er retfærdigt givet loven og den gældende praksis.

Begge problemstillinger vil blive diskuteret, men indledningsvis beskrives først den rolle, som præventiv medicin har fået i moderne teknologiske samfund, fordi vi mener, at de omtalte screeningprogrammer skal ses på baggrund af en generel ændring i opfattelsen af sundhedsvæsnets betydning for befolkningen, dernæst vil vi se nærmere på opfattelsen af sundhedsvæsnet.

Diskussionen om den præventive medicins rolle i moderne samfund er ikke ny. Allerede i 1970'erne begyndte man, at tale om «medikalisering» som en samfundsmæssig proces hvor befolkningen, inklusive politikere, fortolker menneskers livsvaner og holdninger til livets kronologi i en medicinsk kontekst. Medicinsk teknologisk terminologi bliver dermed medbe- 
stemmende for hvordan befolkningen vurderer livsvaner og forhold som oprindeligt blev forstået uafhængigt af videnskabelige forestillinger om sygdom og sundhed. Det er imidlertid ikke de etiske problemer ved selve medikaliseringsprocessen vi fokuserer på. Vort fokus er den udvidelse af sundhedsområdets anliggende og mulige magtbeføjelser, som det tyske reformforslag og de danske screeningsprogrammer afspejler.

Udviklingen behøver ikke i sig selv at vække bekymring, medicinsk teknologisk formåen vil alt andet lige altid kunne gavne befolkningen, men som diskussionen om medikaliseringsprocessen viser, så bør vi være opmærksomme på den magt som den medicinske verden, herunder folkesundhedsvidenskaben, har faet i kraft af udviklingen. Det er netop den medicinske teknologis faktiske succes, vi skal forholde os til ifølge Daniels, som i øvrigt præsenterer et relevant forslag til hvordan staten/sundhedsvæsen kan sikre at borgerne får mulighed for at tage del i beslutninger i sundhedsvæsnet. Forslaget indebærer blandt andet, at beslutninger skal kunne revideres givet evidens og relevante argumenter, hvilket synes aktuelt i forbindelse med screening for kræftsygdomme (Daniels 2002).

Traditionelt er den mest udbredte opfattelse af medicinen eller mere bredt sundhedsvæsnet, at sundhedsvæsnet er til for borgernes skyld, ikke nogle borgere frem for andre, men alle borgere i det danske samfund. Og at sundhedsvæsnet skal sikre, at befolkningen, hvilket ret beset er hver enkelt person, respekteres og ikke udsættes for tvang, herunder også indirekte tvang via misvisende eller direkte manipulerende information om forskellige sygdomme og risikofaktorer. Denne opfattelse er oprindeligt begrundet i en snæver sygdomsorienteret opfattelse af sundhedsvæsnets funktion, frem for en mere bred velfærdsorienteret opfattelse, hvor sundhedsvæsnets forpligtelser udvides til andet og mere end sygdomsbekæmpelse (Kappel 1996). De to opfattelser udelukker ikke hinanden. Bekæmpelse af akutte sygdomme, fx blodprop i hjertet, udelukker hverken primær eller sekundær forebyggelse, eller at sundhedsvæsnet må promovere velfærd i form af andre goder. Men i vores sammenhæng er det vigtigt at fastholde sygdomsbekæmpelsen som lægens oprindelige funktion og se denne funktion i forbindelse med den danske sundhedslov som lægger vægten på, at det er patienten og hans eller hendes ret til at tage stilling til behandling, som er udgangspunktet i relationen mellem borgere og stat (Rossel 1986). Udgangspunktet er altså ikke en idé om det "perfekte liv» som staten skal promovere, men idéen om at modvirke sygdom og andre onder som mennesker faktisk lider under.

Etiske principper og værdier er implicitte i den forstand, at de optræder som antagelser, vi ikke tænker nærmere over i det daglige handlingsliv. For at diskutere vore resultater vil vi derfor først eksplicitere de principper, der kan være tale om. 
To fremtrædende retninger er på spil i debatten. Enten lanceres overvejelser og argumenter af nytteetisk (utilitaristisk) karakter, eller også lanceres argumenter og overvejelser af pligtetisk (deontologisk) karakter. De to retninger i filosofisk etik vurderer en handling på forskellig vis. Anskuet i et nytteetisk perspektiv er en handling at foretrække, hvis den gavner flest. Anskuet i et pligtetisk perspektiv, fokuserer man ikke umiddelbart på handlingers konsekvenser. Det som tæller er snarere, om en handling kan være en forpligtelse for et menneske, dvs. noget, et menneske er påbudt.

De to retninger afspejles i sundhedsvæsnets forpligtelse til både at respektere det enkelte individs selvbestemmelse og samtidig gavne så mange som muligt. På den ene side har vi det nytteetiske princip om at fremme lykken (velfærden) for de fleste og på den anden side har vi det pligtetiske princip om aldrig at bruge mennesker som om de ikke har en værdi i sig selv. De to principper kan let komme i konflikt med hinanden, fordi vi på den ene side kan afveje en enkelt eller nogle få borgeres ret til fordel for hvad flertallet ønsker, imens vi på den anden side er forpligtede til at vise respekt og omsorg over for den enkeltes ret til at træffe sine egne valg. Men de to principper supplerer også hinanden i det danske sundhedsvæsen.

Nytteetiske overvejelser har afgørende betydning, når man planlægger på længere sigt og må overveje konsekvenserne af alternative handlingsmuligheder. Og den side af sundhedsvæsnets virke er selvfølgelig blevet mere aktuel i takt med udviklingen af teknologisk formåen og den brede befolknings krav eller ønske om velfærd, herunder sundhed.

Her er det helt centrale problem hvilke goder vi vil promovere, og hvordan vi prioriterer goderne indbyrdes. Men samtidig er der også problemet om den retfærdige fordeling af goderne, og hvor langt staten kan gå i forhold til den enkelte borger. De spørgsmål fører til pligtetikken, og dens betydning kommer til udtryk i sundhedsloven, hvis indledende paragraffer som omtalt fastslår, at loven er til for at sikre det enkelte menneskes selvbestemmelse, jf. Sundhedsloven (2007). Her er udgangspunktet, at den enkelte borger altid har ret til at blive respekteret med henblik på hvilke goder der er tale om, eftersom staten/sundhedsvæsnet ikke bør forfølge en bestemt ide om «det perfekte liv», men i udgangspunktet alene bekæmpe de lidelser, mennesker lever med.

Det er derfor vigtigt at præcisere, hvad der ligger i udgangspunktet som en anerkendelse af borgernes ret. Som det fremgår af vore resultater er der uenighed om effekten af screeningprogrammer i det hele taget, men samtidig er informanterne enige om principielt om at afvise enhver form for tvang.

Informanternes enighed om at afvise tvang (det tyske forslag) og dermed respektere borgernes ret til at afvise et tilbud, er efter vores mening en tilkendegivelse af at lovgivningen på området lægger vægt på at respektere 
den enkelte borgers ret til selvbestemmelse. Selvom en intervention udelukkende har gavnlige effekter, skal den være et tilbud, dvs. noget borgerne har ret til at afvise.

Informant N3 bemærkede således at selv hvis det hypotetisk antages at screening for kræftsygdomme kun har gavnlige effekter, så bør der altid kun være tale om tilbud til borgerne. Det er imidlertid en bemærkelsesværdig udtalelse, dels fordi den entydigt udelukker tvang, dels fordi den efterlader det indtryk at sundhedsvæsnets forpligtelse er uforenelig med udøvelse af paternalisme over for befolkningen. Der findes forskellige grader af paternalisme. Myndigheder bør stræbe efter en ønskelig paternalisme, det vil sige beslutninger, hvor patienter selv ønsker at overdrage beslutningsmyndigheden (Wulff 1990). Men det er vigtigt at pointere at staten har en forpligtelse til at beskytte befolkningen, $\mathrm{fx}$ ved epidemiske sygdomme, og i sådanne situationer er der ikke tale om tilbud til befolkningen, men om at tilsidesætte borgernes ret til at afslå.

Det er på baggrund af denne forpligtelse, hvis udgangspunkt er den saglige (medicinske) vurdering af sygdommes farlighed for befolkningen, at det tyske forslag og mere generelt screening for kræft skal vurderes, og som bekendt udgør kræftsygdomme ikke en akut fare, som kan sammenlignes med epidemiske sygdomme.

Man kan selvfølgelig indvende, at når staten har ret til at tvinge befolkningen til at ændre livsvaner, $\mathrm{fx}$ ved afgifter på tobak og spiritus, hvorfor har den så ikke ret til at tvinge befolkningen til noget som gavner dens sundhed?

Men her er det vigtigt at understrege, at staten ikke fratager nogen retten til selvbestemmelse ved skatter på tobak og lignende, valget er fortsat muligt, indtil staten indfører forbud. Om forbuddet, $\mathrm{fx}$ mod tobaksrygning, så er rimeligt eller legitimt, kan man diskutere. Informanternes afvisning af tvang er netop udtryk for, at udgangspunktet for en sådan diskussion er det principielle forhold, at staten, uanset hvordan den vil gavne befolkningen, skal respektere borgernes ret til selvbestemmelse.

Staten kan være forpligtet til gribe ind og udøve paternalisme, ligesom den må fastsætte rammer der fremmer sundhed. Men det er ikke det samme som, at den har ret til at bestemme over de goder borgerne faktisk forfølger, $\mathrm{fx}$ ved at promovere en medicinsk eller folkesundhedsvidenskabelig ide om «det sunde/gode liv» og i lyset af den indføre interventioner, som udelukker retten til selvbestemmelse.

Vi vender tilbage til spørgsmålet om «det gode/sunde liv», men vi vil først fremhæve forskellige andre problemer.

De forskellige problemer er vort bud på nogle relevante emner, og baggrunden for at indkredse disse emner har blandt andet været Rawls og spørgsmålet om hvorvidt sundhedsvæsnet bør efterstræbe bestemte goder. Vi tilslutter os Rawls' ide om at staten, så vidt muligt, bør optræde neutralt 
og kun sikre basale behov, ikke stræbe mod at perfektionere befolkningen fx med henblik på sundhed (Rawls 1996).

Helt overordnet kan man pege på det problematiske forhold at evidensen for gavnlige henholdsvis skadelige effekter vurderes så forskelligt af informanterne og så unuanceret af enkelte af dem. På den ene side udtaler N5 at «grundlaget for at argumentere for, at det er så vigtigt at gå til screening, er [...] for tyndt». På den anden side har vi N2, som fremstiller forebyggelse ganske unuanceret og som noget der alene har gavnlige effekter.

Forklaringen på de forskellige synspunkter må bero på informanternes forskellige interesser og positioner i diskursen omkring kræftsygdomme og forebyggelse. Men det burde efter vores mening være hævet over interessebestemte synspunkter, at parterne (informanterne) enigt modvirker den udbredte misforståelse, at screening for kræft kun har gavnlige konsekvenser.

For at modvirke misforståelsen burde man først og fremmest sikre sig, at befolkningen fik en evidensbaseret fyldestgørende information om både de gavnlige og skadelige virkninger ved screening. Og informationen skal være formidlet på en forståelig måde, som gør det muligt at sammenligne de modsatrettede virkninger. På denne måde ville befolkningen få mulighed for, på et sagligt grundlag, at takke ja eller nej til et screeningstilbud.

Her kan man naturligvis indvende, at de gavnlige effekter alt $\mathrm{i}$ alt vil opveje de umiddelbare negative effekter, og det kan vi ikke afvise, men hvis vi inddrager endnu et princip med lange rødder i den medicinske tradition, det såkaldte hippokratiske princip, der også fremstilles som et eksplicit krav om ikke at tilføje skade, mener vi at der ikke kan herske tvivl om, at vores skepsis over for programmerne er velbegrundet (Rossel 1986, 1997; Childress 1994).

I tråd med medicinens oprindelse spiller det hippokratiske princip endnu en rolle. Princippet byder lægen at gavne sin patient og ikke påføre skade. Princippet er nytteetisk, da det fokuserer på konsekvenserne af lægens handling, men i princippet ligger også en tanke, som er en del af vores tradition, nemlig at lægen er forpligtet til at respektere alle mennesker på lige fod.

Princippet benævnes også «ikke skade-princippet», og spørgsmålet er kort og godt om programmerne overhovedet er forenelige med intentionerne i princippet om ikke at tilføje fysiske, psykiske og/eller sociale skader? Efter vores mening taler tallene i tabel 3 for sig selv. Der kan ikke være tvivl om, at de tre screeningsprogrammer ikke er forenelige med denne intention.

På den baggrund er det bemærkelsesværdigt, at ingen af vore informanter kom nærmere ind på, hvordan programmerne faktisk forholder sig til «ikke skade-princippet». De fandt det alle mere nærliggende at tale om 
hvordan sundhedsvæsnet skal «sælge sig selv». Det er selvfølgelig en noget forsimplet fremstilling, men der er en gennemgående tendens til, at parterne tager udgangspunkt i det, de formoder er befolkningens ønsker, frem for at overveje hvad sundhedsvæsnets grundlag og mål skal være.

N4 kom for eksempel med det interessante udsagn, at kun screeningsprogrammer, som har tilslutning fra befolkningen, skal implementeres, uden at N4 nævnte de mulige skader ved programmerne. Hvis der ikke er tilstrækkelig tilslutning til screeningsprogrammet, så kan det ifølge N4 ikke betale sig at tilbyde befolkningen det. Et sådan udsagn bestyrker indtrykket af, at der er en tendens til, at flytte fokus fra saglige og basale forhold. Resultatet er, at sundhedsvæsnet udvikler sig fra at være et sagligt eller evidensbaseret sundhedsvæsen til at være et sundhedsvæsen, der tilbyder eller sælger sine ydelser som varer. Det vil sige et sundhedsvæsen, hvor det er borgerne, der sætter dagsordenen for hvilke forebyggende initiativer, der skal iværksættes, og hvilke, der ikke skal iværksættes.

Vi har ikke været nærmere inde på denne tendens, som også kan identificeres som en del af den omtalte medikaliseringsproces. Men igen står vi over for en udfordring, som sundhedsvæsnet efter vores mening bedst kan møde ved at besinde sig på sin oprindelige forpligtelse og på den baggrund tage stilling til kravet om velfærd. Som vi var inde på ovenfor må sundhedsvæsnet kunne tage ansvar og optræde paternalistisk. Hvis det ikke er muligt, fordi sundhedsvæsnet kun agerer på befolkningens, fx interessegruppers, umiddelbare ønsker, kan det betyde, at forebyggelsesinitiativer, som forekommer oplagte at indføre, og som alle derfor higer efter, indføres uden tilstrækkeligt sagligt grundlag. Et godt eksempel er hormoner til kvinder i overgangsalderen. Mange læger - og medicinalindustrien - var helt enige om, at hormontilskud til kvinder efter overgangsalderen som forebyggelse mod fx menopausale symptomer og knogleskørhed, var det rigtige. Det medførte, at tusindvis af kvinder verden over blev sat i behandling. Dette stoppede brat i begyndelsen af det ny årtusind, da de første videnskabelige forsøg viste, at hormoner til kvinder i overgangsalderen havde langt flere skadelige virkninger end gavnlige (Womens Health Initiative 2002).

Efter vores mening er denne tendens en påmindelse om, hvor vigtigt det er at sundhedsvæsnet udøver intern selvkritik og løbende overvejer om konkrete tiltag faktisk kunne føre til en underminering af tilliden mellem befolkningen og det offentlige sundhedsvæsen og på længere sigt skade sundhedsvæsnets status som upartisk beskytter af den enkelte borger. En sådan underminering kan hverken være til gavn for hele befolkningen eller til gavn for de medicinske fags videnskabelige udvikling.

At der ikke blot er tale om en spekulativ mulighed for en underminering af tillid, men at problemet er reelt, beror efter vores mening på det faktum at vi befinder os i en uigennemskuelig proces, hvor mange kræfter påvirker beslutninger i medicinen (jvf. ovenfor om medikalisering). Som et led i 
denne proces kan de omfattende screeningsprogrammer være medvirkende til, at sundhedsvæsnet glider fra at være, hvad de fleste endnu opfatter som en kvalificeret velgører og beskytter, til noget, de fleste vil søge at undgå. Resultatet af denne udvikling kan i sidste ende ødelægge grundlaget for et offentligt sundhedsvæsen af høj kvalitet. Hvordan denne udvikling vil forme sig, og hvad vi mister henholdsvis vinder (hvis vi vinder noget) når grundlaget forsvinder, er naturligvis kun noget vi kan gisne om, men der er, som det også fremgår af den offentlige debat, god grund til at være bekymret over den retning udviklingen tager (Hartling 2008).

Alle parter burde derfor være enige om, hvad befolkningen skal informeres om, og hvordan det bedst gøres når de inviteres til screening, ligesom man bør tilstræbe internt at afklare evidensen for screening for kræftsygdomme, før man tilbyder befolkningen screening, og spreder budskabet om screening. Befolkningen består ikke af fagfolk, og det er velkendt, at lægfolk ofte misforstår medicinsk information, ligesom det vil være sådan, at diverse interessegrupper altid vil påvirke diskursen og kunne modvirke sagligheden og sundhedsvæsnets neutrale position.

Man kan selvfølgelig stadig diskutere om et screeningsprogram, som både har gavnlige og skadelig konsekvenser, bør iværksættes. Det er muligt at kalkulere i så henseende, men hvis man vil fastholde udgangspunktet for overvejelserne, må man, hvad ingen af informanterne ekspliciterede, vægte mellem de forskellige etiske principper og gå ind i en principiel diskussion. Som nævnt var informanterne bemærkelsesværdigt enige om at afvise tvang, og denne enighed ser vi som et udtryk for hvor stor vægt der faktisk lægges på statens forpligtigelse på borgernes ret til selvbestemmelse. Men dette principielle udgangspunkt forudsætter begrebet om menneskets autonomi og det tilsvarende etiske princip om at udvise respekt for den enkelte borger som autonom person. Her er det afgørende punkt om autonomibegrebets retslige status faktisk udhules i forbindelse med bestemte sekundære forebyggelsesinitiativer.

Hvis det sker, vil den danske sundhedslovgivning blive indholdsløs fordi den så netop ikke sikrer borgeren muligheden for at bruge sin ret til at afslå. Det skal imidlertid understreges, at «Princippet om respekt for autonomi» ikke indebærer andet end netop retten til at afslå, hvilket betegnes en negativ ret (Rossel 1997). Men den danske sundhedslovgivning er et positivt resultat af en samfundsmæssig udvikling, og næppe noget befolkningen $ø n s k e r$ ophævet. Vi tror derfor, at vores informanter er på linje med hvad et flertal af befolkningen ønsker, nemlig at fastholde det pligtetiske udgangspunkt og modvirke udhulingen af autonomibegrebets retslige status.

Det tyske forslag blev ændret fra straf til dem, som ikke deltog i statens sundhedsprogrammer, til belønning af deltagelse. Dette ændrer ikke ved det principielle i problemet. Frem for at alle som udgangspunkt respekteres, så respekterer staten kun de «villige» og ikke alle på lige fod. Konklusionen 
bliver derfor, at hverken «pisk» eller «gulerod» er uproblematiske midler. Men det er jo heller ikke gratis eller uproblematisk for myndighederne at tage borgernes ret til selvbestemmelse alvorligt (Dwarkin 1997).

Men for nu at vende tilbage til spørgsmålet om «det gode/sunde liv». Hvis sundhedsvæsnets udgangspunkt bør være en neutral holdning til ideologiske størrelser såsom moralske og religiøse overbevisninger, kan dets forpligtelse kun strække sig til at beskytte og hjælpe befolkningen. Det udelukker hverken at sundhedsvæsnet kan optræde paternalistisk eller kan påtage sig at fremme velfærd. Men sundhedsvæsnet kan ikke være forpligtet til at fremme sundhed som et særligt moralsk eller religiøst gode. Sundhedsvæsnet må koncentrere sig om de basale goder eller behov, som borgerne faktisk har. Denne holdning til sundhedsvæsnet kommer klart til udtryk hos Wulff, hvor der tales om at udøve «negativ utilitarisme», et synspunkt som kort og godt anbefaler, at «vi ikke skal stræbe efter vage idealer, men i stedet koncentrere os om i så høj grad som muligt, at afhjælpe al den ulykke og lidelse, som vi ser omkring os» (Wulff 1995).

Det er med dette mål for øje, og ikke et eller andet ideal om på langt sigt at skabe en perfekt befolkning med færre syge og længere levetid, at sundhedsvæsnet bør arbejde for at sikre befolkningen rimelige vilkår i form af offentlige institutioner, som modvirker den fysiske og sociale ulighed, som er menneskers faktiske livsvilkår.

Endelig vil vi bemærke, at der selvfølgelig ikke er noget betænkeligt $i$ at befolkningen lytter til medicinen, ligesom patienten til sin læge, eller at staten som omtalt udøver paternalisme. Men sundhedsvæsnet bør være opmærksom på sin aktive rolle i dannelsen af befolkningens ønsker og værdier, for at undgå at medvirke til at nogle hænges ud som afvigere i befolkningen og som udgangspunkt fratages deres ret til at blive respekteret på lige fod.

Et scenarium kunne være, at de som udvikler bestemte typer kræft med det samme betragtes som afvigere i forhold til nogle normer om, hvor mange gange og hvornår de burde have været screenet, når de tilhører en bestemt risikogruppe. Udgangspunktet vil ikke være deres ret til respekt, men at de ikke har den ret.

\section{Efterskrift oktober 2008}

Efter at interviewene og analyserne i denne artikel var gennemført, blev der bragt en ny notits i British Medical Journal om den tyske sundhedslov. I notitsen fremgår det at den tyske regering blev nødt til at indgå et kompromis med lægerne, hospitalerne og patientforeninger på grund af store protester mod den nye sundhedslov. Protesterne gik på, at sundhedsloven ville ødelægge læge-patient-forholdet, og derfor blev forslaget om «tvungen» 
deltagelse i screeningsprogrammer taget ud af sundhedsloven. Men ser man på selve kompromisforslaget er tvangen ikke ude af sundhedsloven (Bundesministerium für Gesundheit 2008b). Tvangen rammer stadig borgeren, nu ikke længere i form af deltagelse i screeningsundersøgelser, men i form af tvungne rådgivningssamtaler omkring screening. For at borgerne kan opnå en nedsat betalingsgrænse i tilfælde af at de senere får en kronisk sygdom, skal de lovmæssigt forsikrede kunne dokumentere at de har ladet sig rådgive om screeningsmulighederne, så snart de når den angivne aldersgrænse for screening. Disse grænser er 20 år for livmoderhalskræft og 50 år for mammografiscreening og screening for tarmkræft. Hvis de tyske borgere ikke kan dokumentere at have deltaget $\mathrm{i}$ en rådgivningssamtale og senere får den pågældende kræftsygdom, så opnår de altså ikke en nedsættelse i deres sundhedsskat. Tvangen er derfor fortsat til stede.

Dette bliver endnu mere absurd, hvis en sådan tvungen rådgivende samtale bygges på et forkert informationsmateriale. Undersøgelser har nemlig dokumenteret, at det informationsmateriale borgere præsenteres for om screening for brystkræft overspiller de gavnlige virkninger og underspiller eller helt undlader de skadelige virkninger af screeningen (Jørgensen \& Gøtzsche 2006; Jørgensen \& Gøtzsche 2004; Slaytor \& Ward 1998).

\section{Acknowledgements}

Hermed vil vi rette en stor tak til læge, ph.d. og seniorforsker Hanne Thorsen for hendes store hjælp med at læse artiklen igennem og komme med gode og konstruktive forslag til at gøre artiklen mere læsevenlig og læseværdig.

\section{Noter}

1 «Versicherte, die selbst etwas für ibre Gesundheit tun, zum Beispiel mit Vorsorgeuntersuchungen, sollen von ibrer Krankenkassen dafür belobnt werden» Ulla Schmidt (Tuff 2006).

2 Her hentyder informanten til tre af kvalitetskriterierne som vedkommende synes er mest vigtige

1. Der skal vere en sikker viden om resultat, altså proeis diagnose.

2. Der skal vore en effektiv behandling

3. Sikker viden om hvordan det ville have gået.(N5) 


\section{Litteratur}

Brodersen, J. (2008) Screening.dk - information om screening for krceft baseret $p a ̊$ videnskabelige undersøgelser. Lastet ned 1. januar 2009 fra http://www.screening.dk

Brodersen, J. \& Lunde, I. M. (2002) Konsekvenser af usikkerhed ved screening. Ugeskrift for loeger, 164 (2), s. 18.

Brodersen, J., Hartling, O., Nielsen, M. \& Gøtzsche, P. (2008) Det informerede samtykke ved screening for brystkræft. Månedsskrift for praktisk loegegerning, 5 (86), s. 551-557.

Brodersen, J., Thorsen, H. \& Kreiner, S. (2007) Validation of a condition-specifik measure for women having an abnormal screening mammography. Value in health, 10 (4), s. 294-304.

Bundesministerium für Gesundheit (2008a) Früherkennung. Lastet ned 1. januar 2009 fra http://www.bmg.bund.de/cln_110/nn_1 168 682/SharedDocs/Standardartikel/DE/AZ/F/Glossarbegriff-Fr_C3_BCherkennung.html

Bundesministerium für Gesundheit (2008b) Gesundheitsreform 2007 im Überblick. Lastet ned 1. januar 2009 fra http://www.bmg.bund.de/cln_110/nn_1 168 248/ SharedDocs/Standardartikel/DE/AZ/G/Glossarbegriff-Gesundheitsreform.html

Conrad, P. (2005) The shifting engines of medicalization. Journal of Health and Social Behaviour, 46 (1), s. 3-14.

Childress, J. F. \& Beauchamp, T. L. (1994) Principles of biomedical ethics. Oxford: Oxford University Press.

Daniels, N. \& Sabin, J. (2002) Setting limits fairly. Oxford: Oxford University Press.

Det etiske råd (1999) Screening - en redegørelse. København: Forfatteren.

Dworkin, R. (1977) Taking rights seriously. Harvard: Harvard University Press.

Gøtzsche, P. C. \& Nielsen, M. (2006) Screening for breast cancer with mammography. Cochrane Database of Systematic Reviews, 4/2006.

Hartling, O. (2008) Solidariteten på spil. Dagbladet Politiken, 14. februar 2008.

Holland, W. W. \& Stewart, S. (2005) Screening in disease prevention - What works? Oxford: Radcliffe Publishing.

Hewitson, P., Glasziou, P. P., Irwig, L., Towler, B. \& Watson, E. (2007) Screening for colorectal cancer using the faecal occult blood test, Hemoccult. Cochrane Database of Systematic Reviews, 2/2007.

Indenrigs- og Sundhedsministeriet (2008) Sundhedsloven. Lastet ned 1. januar 2009 fra www.folketinget.dk/doc.aspx?/Samling/20 042/lovforslag/L74/som_vedtaget.htm

Jørgensen, K. J. \& Gøtzsche P. C. (2004) Presentation on websites of possible benefits and harms from screening for breast cancer: Cross sectional study. British Medical Journal, 328 (7432), s. 148-153.

Jørgensen, K. J. \& Gøtzsche, P. C. (1996) Content of invitations for publicly funded screening mammography. British Medical Journal, 332 (7540), s. 538-541.

Kappel, K. (1996) Medicinsk etik. København: Gyldendal.

Kvale, S. (1997) Interview - en introduktion til det kvalitative forskningsinterview. København: Hans Reitzels forlag.

Lupton, D. (1998) Foucault and the medicalization critique. I Foucault Health and Medicine, red. A. Petersen \& R. Bunton, s. 94-110. London: Routledge.

Malterud, K. (2003) Kvalitative metoder i medisinskforskning - en innføring. Oslo: Universitetsforlaget. 
Morabia, A. \& Zhang, F. F. (2004) History of medical screening: From concepts to action. Postgraduate Medical Journal, 80, s. 463-469.

Raffle, A. E. (2003) Outcomes of screening to prevent cancer: Analysis of cumulative incidence of cervical abnormality and modelling of cases and deaths prevented. British Medical Journal, 326, s. 901.

Rawls, J. (1996) Political liberalism. New York: Columbia University Press.

Rossel, P. (1997) Hvorledes begreber og principper kan forhekse forstanden. Månedsskrift for praktisk loegegerning, 75, s. 1419-1427.

Rossel, P. (1986) Det informerede samtykke. I Medicinsk etik, red. D. Andersen C. E. Mabeck \& P. Riis, s. 252-263. København: FADL's Forlag.

Sackett, D. L., Rosenberg, W. M., Gray, J. A., Haynes, R. B. \& Richardson, W. S. (1996) Evidence based medicine: What it is and what it isn't. British Medical Journal, 312 (7023), s. 71-72.

Slaytor, E. K. \& Ward, J. E. (1998) How risks of breast cancer and benefits of screening are communicated to women: Analysis of 58 pamphlets. British Medical Journal, 317 (7153), s. 263-264.

Sundhedsstyrelsen (1990) Hvorfor - Hvornår - Hvordan? København: Medicinsk Teknologivurdering, s. 28.

Sundhedsstyrelsen (2008) Screening for tarmkroft: Deltagelsesprocentens betydning - En medicinsk teknologivurdering. København: Medicinsk Teknologivurdering 2008; 10 (1). Lastet ned 1. januar 2009 fra http://www.sst.dk/publ/Publ2008/ MTV/screening_tarmkraeft/MTV_tarmkraeft_net_final.pdf

The Nordic Cochrane Center (2008) Lastet ned 1. januar 2009 fra http://www.cochrane.dk

Tuff, A. (2006) Germany will penalize cancer patients. British Medical Journal, 333, s. 877.

Tufts, A. (2008) German patients escape financial penalties for not following their doctor's advice. British Medical Journal, 336 (7635), s. 65.

Verweij, M. (1999) Medicalization as a moral problem for preventive medicine. Bioethics, 13 (2), s. 89-113.

Verweij, M. (1998) Preventive medicine. Utrecht: Zeno.

Williams, S. J. \& Calnan, M. (1996) The limits of medicalization. Social Science and Medicine, 42 (12), s. 1609-1620.

Wilson, J. M. G. \& Jungner, G. (1968) Principles and practice of screening for disease. Geneve: WHO.

Wulff, H. R. (1995) Den samaritanske pligt. København: Munksgaard.

Wulff, H. R., Pedersen, S. \& Rosenberg, R. (1990) Medicinsk filosofi. København: Munksgaard.

Womens Health Initiative (1972) Menopausal hormone therapy. Lastet ned 1. januar 2009 fra http://www.nhlbi.nih.gov/health/women/pht_facts.pdf

Zola, I. K. (1972) Medicine as an institution of social control. Sociological Review, 20, s. $487-503$. 